\title{
Relating Word-of-Mouth to Corporate Reputation
}

\author{
MARTIN WILLIAMS \\ University of Technology Sydney, Australia \\ FRANCIS BUTTLE \\ Macquarie University, Australia \\ SERGIO BIGGEMANN \\ University of Otago, New Zealand
}

This paper explores the relationship between customer-generated word-of-mouth (WOM) and corporate reputation. After a concise literature review, we present several insights from case study analysis of three organizations. Our main finding is that customer dissatisfaction and negative word-of-mouth (NWOM) are thought to have strong downside consequences for corporate reputation. Yet, positive WOM does not appear to have equivalent upside significance for corporate reputation. NWOM often occurs as customers express dissatisfaction because of substandard customer service. However, it is when these issues or other negatively connoted stories find their way into the public domain with the potential of wider electronic WOM spread through the Internet that reputation suffers. Fear of reputational damage causes great anxiety to the organizations' senior management. Reputations are shown to be fragile. Damage limitation strategies are implemented in all three organisations.

\section{Introduction}

Corporate reputation is a powerful influence on whether prospective consumers become customers (Boyd et al., 1994; Helm 2006). While the impact of carefully structured corporate communications on corporate reputation is fairly well understood (Cornelissen 2000), our focus is on trying to understand the association between customer-generated word-of-mouth and corporate reputation. We report findings from a multiple case study that offers insights into the interaction between word-of-mouth and corporate reputation, and the responses of managers in those organizations to the threats and opportunities WOM creates.

\section{Literature review}

There is no consensus on what counts as corporate reputation. Weigelt and Camerer (1988, p.1) suggest that, "a corporate reputation is a set of attributes ascribed to a firm inferred from a firm's past actions". These behaviours are built up over a period of time and differ from image, which, according to Balmer (1998), is composed of the latest beliefs about an organisation. However, from a consumer perspective corporate reputation and image are closely related (Shenkar \& Yuchtman-Yaar 1997).

According to Selnes (1993) and Fombrun (1996), corporate reputation is the perceptual representation of a firm's overall appeal compared to its rivals. Koronis and Ponis (2012) argue that corporate reputation is the accumulated trust and positive evaluations of the organisation's stakeholders. Although corporate reputation can and does vary between different stakeholders (e.g. between investors and employees), from a marketing perspective 
it can be thought of as a market-validated intangible asset (or liability) (Barney, 1996; Black et al., 2000; Hansen, et al. 2008).

Davies and Miles (1998) believe that people form their beliefs about an organisation based on their particular relationship with it and their knowledge of its character, ability, products, services and behaviour. Of these influences, Dowling (2004) argues the organisation's behaviour, including that of the CEO, is the prime determinant of its reputation. These perceptions may change over time, even though the firm's attributes remain the same.

As Gray and Balmer (1998) note, everything a corporation "says, makes or does" in some way communicates. For instance the perceptions about a firm's attitude towards Corporate Social Responsibility (CSR) affect not only customer's perception of corporate reputation, but also consumer trust and loyalty (Stanaland, Lewin, \& Murphy, 2011). However, what a corporation does not say can send equally powerful signals. Balmer and Greyser (2002) further divide communication influences on corporate reputation into two clusters: controlled and uncontrolled. There are two clusters of corporate-controlled influence on corporate reputation: primary and secondary. Primary influences include product performance, organisational and leadership behaviour; secondary influences include advertising, PR, graphic design, and sponsorship. The uncontrolled influences on corporate reputation are deemed "tertiary" by Balmer and Greyser (2002). These include "spin” and WOM, the focus of this research.

An organisation's reputation therefore results from a constellation of influences including WOM (Balmer, 1998; Balmer \& Greyser; 2002; Moffitt, 1994). Other authors stress the valence of reputation. For them, reputation is an overall evaluation of a firm as being substantially good or bad (see Frombrun, 1996; Weiss et al., 1999). Helm (2007), in her synopsis, states that reputation is "the individual's perception of the general estimation in which a firm is held, good or bad” (p. 190). While Walsh and Beatty's (2007) perspectives on the customer and their inclusion of service quality in the mix might suggest customers were of a primary influence on corporate reputation, it would be reasonable, under Balmer and Greyser's (2002) model of corporate-controlled sources, to assume customers fall into category of "uncontrolled" influences.

In facing performance ambiguity, a good reputation will serve as a proxy for the level of service quality (e.g., Kirmani \& Rao, 2000; Rubin, 1995), while a trustworthy reputation, one that stresses credibility, reliability, honesty and benevolence (Ganesan, 1994; Fombrun1996) can help firms build consumer loyalty and survive crises, as well as gain more favourable treatment from regulators and the media (Bloom et al. 2006; Frombrun, 2001). In fact, the PR industry's Weber Shandwick The Company Behind the Brand: In Reputation We Trust Report (2011), highlights two key discussion points: corporate reputation provides product quality assurance and consumers shape reputation instantly. More recently, Richard and Zhang (2012) stress the positive influence of corporate image on customer commitment and customer satisfaction. Dowling (2004) suggests that a good corporate reputation not only helps set the expectations of stakeholders and competitors, but creates an emotional and intellectual bond with employees and target customers, and enables the business to sustain superior profit outcomes over time. 


\section{Literature Linking Word-of-Mouth (WOM) to Corporate Reputation}

Despite what might seem like an obvious link, there is relatively little literature on the connection between WOM and corporate reputation - or electronic word-of-mouth (eWOM) (see Park and Lee, 2007). Rogerson (1983) described firms with excellent reputations as having more customers, enjoying positive word-of-mouth (PWOM) from those customers, resulting in higher volumes of new customer acquisition and reduced churn. Research by File et al. (1994) in the non-profit context linked trust to higher donations, while Fombrun (1996) linked WOM output within networks to professional organisations' performance. Cornelissen (2000) endorsed WOM's contribution to corporate reputation, while Falkenreck and Wagner (2010) found that WOM's effects on corporate reputation vary according to culture. Casalo, et al. (2007) observed a direct, positive and significant relationship between customers' satisfaction with online interactions and commitment to a website. Perceived reputation was also seen to have an indirect effect on the consumer's commitment through the trust endowed by the consumer. Sitchman's (2007) research amongst customers, found trust in service providers has a significant impact on purchase intention and WOM, while Walsh et al. (2009), also from a customer perspective, found customer satisfaction and trust both make independent contributions to corporate reputation, which in turn predicts customer loyalty and WOM. However, these authors were unable to verify a two-way relationship between WOM and corporate reputation, with WOM being both cause and effect.

Hoyer and MacInnis (2001) found WOM was the most credible and objective influence on corporate reputation. Bharadwaj et al. (1993) stated when a purchase is high in experience or credence attributes, reputation serves as an important proxy for more detailed evaluation. Söderlund (1998) found that providing consistently high customer satisfaction builds reputation and insulates firms from high levels of customer churn. Reuber and Fischer's (2005) research also shows PWOM is stimulated by high levels of customer satisfaction, implying that WOM is perhaps both cause and effect of corporate reputation, on which customer-employee interaction may also have a significant effect (Davies et al. 2010). More broadly, Davies et al. (2003) argue that "what matters is the actual experience, and the match between it and our expectations. Get both right and a good reputation is guaranteed" (p. 64). Thus, in meeting or exceeding customers' expectations, customer satisfaction is achieved, PWOM is uttered and good reputations are built.

However, reputation is fragile. While reputations may take time to build (Balmer \& Stotvig, 1997) they can easily be destroyed. A single event can sweep aside years of "banked" goodwill. Performance of one of the world's largest jewellery retailers, Ratner Group, shifted from sustained profits to significant losses when Chairman, Gerald Ratner made the following remark: "People say, 'how can you sell this for such a low price?' I say, 'Because it's total crap'.” This story was published on the front page of the UK's Sun newspaper, and provoked a massive volume of NWOM (Peck et al. 1999, p. 249), becoming widely referred to as "doing a Ratner" (Daily Telegraph, 22 December 2007). A growing body of research shows that the reputation of the CEO is an important driver of corporate reputation (Dümke 2003). The 1998 Burson Marstellar study Maximising Corporate Reputations found that a CEO'S reputation accounts for 40 percent of a company's standing as viewed by its stakeholders. Dowling (2004) maintains the CEO and the integrity of the top team, the performance of the board, and the executive managers also play a crucial role in personifying and creating trust and confidence in the firm.

The more recent, Burston Marsteller report Managing Corporate Reputation in the Digital Age (2011) recommends the promotion of PWOM internally amongst employees to reduce 
NWOM and employee churn. The report also frets about the effects of real-time viral communication through social media platforms, blogs and tweeting that accelerates the spread of bad news, prompting further NWOM and potentially damaging corporate reputation. United Airlines suffered significant NWOM when a customer's baggage handling experience was turned into a song and posted on YouTube. Thus far "United Breaks Guitars" has received over 12.5 million hits. However approximately 30,000 clip-related comments also contribute directly to NWOM and to loss of corporate reputation. A sample comment from one viewer: "United sucks shit". ${ }^{1}$ Thus many companies routinely monitor blogs about their products, services and reputations, while full-time bloggers report on NWOM and actively participate by correcting facts and misconceptions (Allsop, Bassett \& Hoskins, 2007).

\section{Three Case Studies}

Whilst this literature review suggests that there is a high level appreciation of the possibility that customer-generated WOM may have an influence on corporate reputation, there is no case-based evidence that organisations appreciate the connection or how, if at all, they attempt to manage this phenomenon. Therefore, our research question is: "What do organisations understand of the relationship between customer-generated WOM and corporate reputation, and how, if at all, do they manage it?"

A multiple-case study was conducted with a replicated design, following the recommendations of Yin (1994, 2003). Perry et al. (1999) consider the qualitative research methodology of case studies ideal for marketing-oriented research, as they enable theory building, in contrast to the quantitative approach of testing and verifying existing theory (Bonoma 1985; Lincoln and Guba, 1985; Tsoukas 1989). In fact, case studies have been used to understand both WOM behaviour (Gremler 1994) and consumer behaviour more generally (Gwinner et al. 1998). Thus this qualitative study was undertaken in three organisations having operations and offices in Australia: a regional energy company and two multinational organisations - one from the financial services sector and the other from the non-profit (NP) welfare sector.

Primary data sources and collection methods comprised interviews with individuals (later transcribed), observation and additional texts such as reports and customer communications (Scapens 1990). Snowball sampling to gain access to interviewees, having initially gained access at the highest levels of those organisations (Lindlof 2010) was employed. Data for the cases was gathered from 54 in-depth face-to-face interviews (Daymon and Holloway, 2002) with 33 respondents, and was compiled over a lengthy period. Interviews were purposive and theory-driven (Miles \& Huberman, 1994), conversational and loosely structured (Rubin and Rubin, 2005).

$\mathrm{N}$-Vivo software was used both as a data repository and analytical tool. Nodes were created for a number of constructs including reputation, image, identity and goodwill. However, as noted above, the concepts of image and reputation are difficult to distinguish (Gotsi \& Wilson, 2001; Shenkar \& Yuchtman-Yaar, 1997). So for this analysis, as far as possible, references made directly to "image" have been excluded, thus giving a clearer picture of corporate reputation and WOM. 


\section{Findings}

Many connections between WOM and corporate reputation were encountered throughout our case analyses. Those we highlight in this paper illustrate a number of important findings. The association between WOM and corporate reputation is most pronounced within customer service departments, sales force and communications arenas of the organisation, including PR and its use of cause-related marketing.

Consistent with Jahdi and Acikdilli (2009) and Stanaland et al. (2011), trust is important to the reputation of all our sample organisations. In the for-profit cases trust is closely related to length and depth of the service relationship. A respondent from the financial case told us that PWOM would be relevant to how long they have been a customer and how long they've dealt with that individual: "my first role is to gain their trust ... to demonstrate my responsibility and gain their trust ... which contributes towards our brand standing and reputation" (FCC7).

Trust is an important building block of corporate reputation in the NP. It is closely associated with the NP's uniformed officers going about their welfare business. A respondent from the NP said: "If people can't trust [us], who can we trust? ... and that was a bit of a key to it. [The Public Trustee] had total trust in the uniform, not me, in the uniform and what I represent" (SPM1).

Trust in the NP has also been built from past actions. The NP's reputation has been built over the long term, perpetuated by its legends, and war stories. In fact "goodwill" and "trust" built in this way appear to have had significant impact on reputation amongst their aging donor base. A respondent from the NP explained that "We were there for them in the war years and has been lingering for some generations now ... What we did then lingers for us, the trust and credibility element” (SPM1).

Trust and PWOM are also linked to the NP's ability to deliver a high percentage of donations to its welfare clients, rather than be consumed in administration. Participants believe this perpetuates PWOM and contributes to donors' continuing (loyalty) giving. Thus a respondent from the NP said that "In terms of WOM, people would be saying, [we] have a good reputation ... we have a high level of applying the dollar that's donated to the work that we do” (SPM2).

In the service cases, senior managers believe that PWOM can be stimulated by enhancing delivery of customer service, and that high levels of customer satisfaction will promote customer 'goodwill' and have a positive effect on the organisation's reputation. The energy company may benefit from a heightened level of trust because it is a government owned company. An energy interviewee explained that "Home Suite customers choose us for a whole range of reasons. The principal one is ... we are a GOC [Government Owned Company], and publicly accountable, [in a referral situation] ... there's [an added] sense of trust that we will do the right thing” (EMHS2).

In fact, a customer orientation has helped the energy company build the brand, as indicated in this comment from an interviewee, who felt "That positive brand [and its reputation] comes from primarily the interactions we have with people. The staff in the frontline [are] very customer focused" (EMD1). However, customer satisfaction in the consumer divisions of the for-profit organisations is deemed to be low, and PWOM is therefore scarce. The financial services company has invested significant resources in improving service levels, with anticipated downstream effects on customer satisfaction, PWOM and reputation. A financial 
services respondent said, "The reputation and WOM of [the brand] was great brand, but [service delivery] was out the door. And now [we're] trying to match the service with the brand name again, which is fantastic. The thing that blew me away when I started here was the brand never matched what service was being offered. But now [we're] trying to bring the two back together" (FCSM4).

Though PWOM is not a communications objective in any of our cases, advertising and marketing departments are keen that creative content has 'talkability' and that advertising content will stimulate conversation and PWOM, and contribute to building trust and the reputation of the organisation. The NP believes that trust lies at heart of the organisation's reputation and that trust can be reinforced through advertising. The energy organisation describes their communications strategy with the public as having created "a high degree of trust”. The multi-channel, multi-media strategy they have employed, including advertising, public relations [PR], sponsorship and events management requires more managerial effort and expertise, but has stimulated WOM and built trust in the brand. "The brand is very strong, the brand is very trusted, [we have] put a lot of time and effort into making it so," asserted one respondent (EAM3). When discussing donor acquisition, an NP interviewee stated: "Trust is an amazingly important thing and advertising has a role of reinforcing trust, and reinforcing awareness and the values in the organization" (SFM3). Another NP interviewee added that "Advertising [on television] plays a role [in support of WOM] that none of us could even contemplate the power of ... it was a combination of communication, advertising, awareness and trust” (SVC6).

The energy organisation's endorsement of the Wallabies Rugby World Cup team in advertising, and PR, assisted in establishing their new brand identity, particularly in key decision-makers' minds, and after 18 months resulted 60 percent awareness as measured by independent consumer research. When asked whether the brand was being discussed openly an interviewee responded: "We have the strongest interstate brand in both Sydney and Melbourne. Our brand in Melbourne is stronger than any Sydney suppliers, and our brand in Sydney is stronger than any Melbourne suppliers” (EAM3).

All three cases equate the use of celebrities in advertising, PR and direct mail together with catchphrases and their taglines as having significant impact on PWOM and their corporate reputation. For more than 30 years, the financial case has employed famous actors such as the late Peter Falk (the star of long running Colombo TV series) to endorse the brand, and though it has not used a certain slogan for 30 years, the organisation's historical tag-line remains alive in customers' memory. It is still widely talked about, ensuring a consistently high WOM output. A respondent from the financial case thus commented: "We have a reputation for our advertising ... some of our campaigns are iconic. 'our tagline' is iconic. It is recognised by people of my generation and I wasn't alive when it was created ... [our] marketing has been very clever in creating memorable, and talked about campaigns” (FBM5).

These sentiments were echoed by an interviewee from the NP: "Those [advertising taglines] phrases seem to become imbedded in the 'speak' of our Chairmen and volunteers ... so WOM is there, how else do young people who I see on the street have that feeling that they must give to [us]? Where does that come from other than grandma or grandpa telling mum and their mum telling them?” (SFM3).

Aligning the organisation to innovations has stimulated PWOM in the financial case. Innovations associated with the environment and energy-saving stimulate PWOM as in the energy case's carbon offset products. Their sponsorship of the annual solar car rally has also 
enhanced their reputation. An energy respondent said that "Innovative products around energy saving [and the rally] ... stimulate talk and adds to our own reputation” (EAM3).

All three case organisations also attempt to leverage their reputations commercially. Alliance partnerships bring external reputations to bear on the reputation of the alliance instigator. In all three cases, reputational benefits had been derived from these associations. While these benefits where most pronounced around innovative products and services, the standing of well-respected and reputable brand names enhance the company image by association as well as providing the potential leverage of the alliance partner's customers. A financial company interviewee explained that "We've teamed up with one of the Big 4 and used their reputation with effect ... and they've used ours" (FBM6). Of their co-branded credit card's brand-leading position, a financial case respondent told us that "it's a part of our loyalty model ... we've leveraged the [the partner airline's] reputation and [our Brand] to give our customers a credible competitive offer" (FCM4).

Reputation is also viewed as an asset. The for-profits' sales forces leverage the testimonials of high profile individuals from organisations with strong reputations. These referrals can have major beneficial effects in bringing in new business. A financial company interviewee explained that, "Customer testimonials from reputable brands are perhaps the most important thing we could have in new business pitches, we do this all the time" (FCM3). An energy interviewee similarly noted that: "We use other companies' reputations [in business pitches]. For instance, we've just won McDonald's business along the Eastern Seaboard, its big for us ... we'll hammer that to death" (ESM6).

The reputations of the for-profits are also strongly associated with social causes and causerelated marketing (C-RM) activity. An interviewee in the financial case stated that "Our employees ... about a third of them are involved in local social activity which is encouraged by [the organisation] ... that ... does a lot for our reputation" (FRM8). An interviewee from the energy company similarly explained that "We get involved in many cause related activities, such as the Rescue Helicopter and green causes too, which does our reputation good" (EAM3) Such activities also help to build "a bank of goodwill”. An energy respondent discussing these activities thus commented that "They build reputation reserves and help bank consumer goodwill for us” (EMD1).

In the services companies, WOM measurement has been strongly linked to SERVQUAL market research measures of customer satisfaction, particularly to "willingness to recommend". Reputation research is carried out separately. The NP uses cross-industry research to provide guidance on its image and reputation, and is recognised as a "highly trusted” brand. The energy case benchmarks its customer performance using RepuTex reputation measurement, which assesses companies in four key areas, corporate governance, environmental impact, social impact and workplace practices, comparing its reputation to others within the industry in which it has consistently scored highly, reaching first or second on the ranking.

It also uses Y\&R's brand asset valuator. However, neither service companies' reputation measures directly relate to customers or customer satisfaction. Though managers recognise that reputation and WOM have links, the association between WOM and reputation has not been considered specifically within these measurements. An interviewee from the energy company observed that “We use John Hewson's RepuTex for our [industry] comparisons, it doesn't include specific customer satisfaction scores or any WOM measures, perhaps it should” (FRM9). 
Strong evidence connecting service-driven NWOM to reputation was discovered. An energy respondent explained that "The goodwill we have built up can be severely damaged by outages and loss of power ... it affects our reputation in the marketplace” (EHS2). Reputation is further eroded with constant power outages, which the energy company has recognised and has attempted to address through customer data analysis of heavy usage. In summer they make targeted customer appeals to ration use of such appliances as air conditioning which put strains on the grid. An energy interviewee noted that "to reduce the negativity and damage we employ our data [CRM] systems and processes to try and counteract heavy usage” (EMD1).

Both service organisations employ their CRM systems to pinpoint potential customer problem areas where NWOM and reputational damage can occur. The financial company uses these to analyse customer continuing purchase loyalty. Where issues are identified from the data, retaliatory action is triggered. The energy company enacts procedures which identify those less profitable "heavy cost to serve" customers, who are more prone to create NWOM, and put strains on customer service and costs.

Both for-profits have implemented complaints-management processes to capture and resolve customer complaints before they go viral. In fact, they put high priority on customer complaints, which are monitored for their satisfactory resolution through their CRM processes. Though NWOM driven by customer dissatisfaction with substandard service is of high concern to the service organisations, NWOM from negative media comment is held in greater anxiety by all our cases. In these circumstances, the respondent assiduously adhere to their established crisis management processes.

Under these procedures, risk assessments are also carried out department by department. They believe NWOM from media criticism affects multiple audiences, travels faster, and damages employee morale, as well as the organisation's reputation. In fact, the employee affects were deemed highly significant. A respondent from the energy company explained that "It is damaging [to our reputation] because it slows down productivity. Morale gets affected, and people don't feel certain, it creates uncertainty, not necessarily depending on how damning it is. You just don't want to be on the receiving end of it, it causes rumours in the workforce and amongst our customers and gets totally out of control” (EHS2).

In the financial services, company managers believe NWOM circulating in the media can have significant adverse affects on service customers and employees and online media effects can exacerbate this. While managers are not confident they can handle media contagion, they are significantly concerned when propelled by viral eWOM, that damage can be contained at all. An energy company respondent observed that, "To-day the fact that everybody is connected only speeds the whole process up and the damage” (EAM3).

The NP has noticed that what it does not say has affected its reputation and instituted processes to "communicate how it is". Unlike the service organisations that worry about the effects of NWOM and damaged reputation on financial markets, the NP has been able to directly link negative media exposure to significant reductions in donations. Media revelations of abuse in boys' homes, and more recently the sale of aged care nursing homes, created negative publicity and NWOM and tarnished the NP's reputation leading to significant donation shortfalls. A respondent from the NP noted that, "We don't like media comment, it gets out of hand and we can't control it when it damages our reputation” (SPR4). Furthermore, when closely associated NP's are likewise under scrutiny, the reputations of the whole charity sector are negatively affected, reflected in reduced donation receipts across the board. 
In each of our cases, the impact of senior management on PWOM, NWOM and corporate reputation was significant. It was hard for our respondents to distinguish between the CEO's personal reputation and the organisation's reputation. The financial case demonstrates the impact of the CEO's reputation on the signing of high profile PWOM - stimulating alliance partnerships as well as attracting new business. A financial case interviewee observed that “The CEO's personal reputation and his networks have an impact on our new business and our negotiations with alliance partnerships, his reputation and ours go hand in hand" (FCM3). In the energy case, an interviewee felt that the CEO was seen to have had direct influence on establishing the new brand, stating that "Our CEO came with a great reputation with his ability to fix the State's transport, and his credibility had a big impact on the establishment of the [Company] brand” (EAM3). The NP's Commissioner is deemed to be highly influential on building reputation and in networking with key influencers, leading to higher-level donations. A respondent thus noted that, "Reputation in [our organisation] is led from the Commissioner down, and that's networking and donations” (SPM1).

However, in the energy case, the CEO's reputation was significantly associated with NWOM. The energy case received NWOM from media comment associated with the suicide of its CEO, reputedly from pressure of the job and criticism of infrastructure failure. His successor, appointed by its major government stakeholder, was accused of child abuse of which he was later cleared, while another successor was fired for insider trading. The cumulative damage to reputation of the energy brand from consumer NWOM stimulated by cronyism, self-interest and lack of commercial realities resulted in the community losing confidence in the organisation. The brand damage was catastrophic. On every major brand measure the brand had the lowest reputation ratings in the country compared to other utilities (Roberts and Alpert, 2010).

\section{Conclusions}

PWOM's effect on reputation is not fully appreciated in our three organisations. This, we suspect, is due to a lack of appropriate identification or measurement. However, they do understand that reputations are fragile assets that can easily be destroyed by media-hyped NWOM, compounded by viral eWOM. Managers are increasingly concerned about NWOM's effects on employees, and of further pressure applied by stakeholders. They invest heavily in strategies and processes such as crisis management and complaints management to nip reputation-damaging NWOM in the bud. PWOM (or NWOM) is largely viewed simply a by-product of the for-profits' customer service performance, and organisational communication efforts driven by PR, including cause-related marketing.

While managers believe PWOM contributes to reputation, no processes are in place to directly influence it. Thus PWOM, without a value being placed on it may be under-utilised as a tool for enhancing corporate reputation. On the other hand, NWOM is better understood for the damage it does to reputation. However, NWOM may have more negative effects on corporate reputation than is currently appreciated.

\section{Limitations}

Case study research, of course, is limited as to its "generalisability". This study focused on three organisations in widely different industries - financial services, energy supply and fundraising. Whilst all three have similar marketing department structures for business-tobusiness and business-to-consumer segments, customer (donor) acquisition goals and 
organisational communications, it is impossible to generalise from a relatively small sample (Smith 1978). A second limitation is that data collection was confined to managers working within the three subject organisations and did not, with one volunteer donor exception, include customers or donors. Thus, this analysis from the managers' points of view forms a basis for generalisation but in no way provides "the ultimate truth" (Guba \& Lincoln 1994), thus caution must be exercised in applying this study's findings beyond the particular organisational environments (Yin 2003).

\section{Recommendations}

In a world driven by the Internet and with the consequent expansion of channels of communication (Hennig-Thurau et al. 2004), the need for out-bound messaging to "talk with one voice" is understood by managers. Further, the reputation affects of NWOM circulating amongst employees can be profound, whether senior or employees at large. Therefore, understanding of how organisations manage customer-generated WOM and its influence on reputation is paramount, and may be of a higher importance than the "tertiary influence" Balmer and Greyser’s (2002) “Total Corporate Communications” nomenclature implies.

In determining a central point for WOM management, the role of PR in WOM is indicated to be high particularly in NWOM prevention, where the CEO has a direct interest. Internal communication also plays a role central to PR. However, whilst other departments such as customer service and the sales force may not have as a strong a claim for WOM centrality within the organisation, they also play a significant role in customer's likelihood of uttering PWOM or NWOM. Therefore the organisation should attempt to have these departments form cross-functional working groups to analyse WOM and NWOM to assess whether new understandings can be arrived at, beneficial to the organisation in terms of PWOM stimulus and NWOM reduction. As marketing departments normally lie beyond the jurisdiction of customer service, this creates a challenge. Whilst it may provide a barrier to management to funding a cohesive program to positively affect reputation processes within the organisation, it is recommended that they be included to attempt to co-ordinate a more unified organisation-wide response.

Current reputation measurement instruments are inclined not to include customer (satisfaction) measures (see Davies et al. 2003) and therefore may render inadequate measurement of reputation. The results of this research tend to suggest that customer experience plays a significant role in formation of corporate reputation and that future measurement of a firm's reputation needs to take this into account. In a world where corporate entities are increasingly marketing their products and services to consumers at the corporate rather than business unit level, service companies are advised to view reputations not only from a financial perspective but also from that of the consumer. Corporate reputation measurement instruments have largely ignored the point of view of the customer. This suggests a thorough overhaul of current practices similar to that recommended by Fombrun et al. (2000), who established "The reputation quotient", a multi-stakeholder measure of corporate reputation.

These cases have established that PWOM utterance occurs where consumer trust is high. Trust has been extensively recognised as an essential ingredient for successful relationships (Crotts \& Turner, 1999; Garbarino \& Johnson, 1999). Trust is a high order construct comprised of variables such as others' confidence, predictability, ability, expertness, intentions or motives, motivation to lie, business sense and judgement, altruism, loyalty, integrity, congruence, consistency, fairness, character, openness of management, linking, 
respect, faith, acceptance, and security. In fact, Seppänen et al. (2007) find 22 different dimensions of trust, amongst the major theoretical approaches in contemporary literature. Within business relationships trust benefits by decreasing decision-making uncertainty (Svensson 2001), thus smoothing the relationship and creating confidence that the trustworthy party can be relied on.

Trust has a dual effect on WOM and corporate reputation. On the one hand a trustworthy organisation is viewed as featuring a combination of honesty, benevolence and reliance that depends on past behaviour and expectations of future behaviour (Sullivan et al. 1981), while on the other as trust decreases uncertainty, customers are more willing to take a risk and endorse the actions of an organisation, through PWOM. As trust is thought to trigger action, assessing trust levels when PWOM is spoken about an organisation can contribute to further understand the idea of trust and risk taking. Thus managers should bear in mind the critical importance of keeping high levels of trust among customers, and amongst employees so PWOM as opposed to NWOM is uttered.

In this regard, managers should also put social and environmental cause-related marketing contributions near the top of their reputation agendas, however other WOM stimuli such as product innovation can contribute. So stimuli that exist beyond the company, such as alliance partner associations and their brands which have innovative or hi-tech products or alternatively develop new ones, which together, might offer value to their customer bases with a view to reputation enhancement. They should also carefully observe Honesty (the belief that the other is credible) and Benevolence (the belief that the other acts in a manner beneficial to the other in both its consumer and business markets) to encourage trust, customer advocacy and WOM. Thus a study that seeks for signs of trust behind the reasons why people give PWOM needs further exploration.

Significantly, this paper has revealed that the effects of NWOM may be most significant and should not be ignored. Therefore perceptions of reputation from both PWOM and NWOM points of view would be necessary to gain further insights to judge WOM's specificity towards reputational perceptions and to validly represent impact of WOM on the collective construct of corporate reputation of a firm, the effects of NWOM across all stakeholder groups require further investigation.

\section{References}

Allsop, D.T., Bassett, B.R., \& Hoskins, J.A. (2007). Word-of-Mouth Research: Principles and Applications. Journal of Advertising Research, 47(4), 398-411.

Balmer, J.M.T. (1998). Corporate identity and the advent of corporate marketing. Journal of Corporate Marketing Management, 14(8), 963-996.

Balmer, J.M.T. \& Gray, E.R. (1998). Managing corporate image and corporate reputation. Long Range Planning, 31(5), 695-703.

Balmer, J.M.T. \& Greyser, S.A. (2002). Managing multiple identities. California Management Review, 44(3 Spring).

Balmer, J.M.T. \& Stotvig, S. (1997). Corporate identity and private banking: a review and case study. International Journal of Bank Marketing, 15(4/5), 169-185.

Barney, J. (1996). Gaining and Sustaining Competitive Advantage. Addison Wesley. New York.

Bharadwaj, S.G., Varadarajan P.R. \& Fahy, J. (1993.) Sustainable competitive advantage in service industries: A conceptual model and research propositions. The Journal of Marketing, 57(4), 83-99. 
Black, E.L., Carnes, T.A. \& Richardson V.J. (2000). The market valuation of corporate reputation. Corporate Reputation Review, 1, 21-31.

Bloom, P.N., Hoeffler, S., Keller, K.L., \& Basurto Meza, C.E. (2006). How social cause marketing affects consumer perceptions. MIT Sloan Management Review, 47(2), 1-9.

Bonoma, T. (1985). Case research in marketing: opportunities, problems, and a process. Journal of Marketing Research, 12, 199-208.

Boyd, W.L., Leonard, M. \& White, C. (1994). Customer preferences for financial services: an analysis. International Journal of Bank Marketing, 12(1), 9-12.

Burson-Marstellar (1998). Maximising Corporate Reputations Report.

Casalo, L.V., Flavian, C., \& Guinaliu, M. (2007). The Influence of Satisfaction, Perceived Reputation and Trust on a Consumer's Commitment to a Website.

Journal of Marketing Communications, 13(1), 1-17.

Cornelissen, J. (2000). Corporate image: an audience centred model. Corporate Communications: An International Journal, 5(2), 119 - 125.

Crotts, J.C., \& Turner, G.B. (1999). Determinants of intra-firm trust in buyer-seller relationships in the international travel trade. International Journal of Contemporary Hospitality Management, 11(2/3), 116-123.

Davies, G. \& Miles, L. (1998). Reputation Management: Theory versus practice. Corporate Reputation Review, 2(1), 16-27.

Davies, G., Chun, R. \& Kamins, M.A. (2010). Reputation gaps and the performance of service organizations. Strategic Management Journal, 31(5), 530-546.

Davies, G., Chun, R., Da Silva, R.V. \& Roper, S. (2003). Corporate Reputation and Competitiveness. Routledge. London and New York.

Daymon, C., \& Holloway, I. (2002). Qualitative Research Methods in Public Relations and Marketing Communications. Routledge, Oxon, UK.

Dowling, G.R. (2004). Corporate reputations: Should you compete on yours? California Management Review, 46(3), 19-38.

Dümke, R. (2003). Corporate Reputation and its importance for business success. Master's Thesis. Oxford Brookes University (Business School). GRIN Verlag, Holland.

Falkenreck, C., \& Wagner, R. (2010). Impact of Direct Marketing Activities on Company Reputation Transfer Success: Empirical Evidence from Five Different Cultures. Corporate Reputation Review, 13(1), 20-37.

File, K.M., Prince, R.A., \& Cermack, D.P. (1994), "Creating Trust with Major Donors: The Service Encounter Model”. Non-profit Management and Leadership, 4(3), 269-283.

Fombrun, C.J. (2001). Blackwood Handbook of Strategic Management, Chapter 10 (eds) Hitt, M., Freeman, R. E., and Harrison, J. S. Blackwell, Oxford. UK.

Fombrun, C.J. (1996). Reputation: Realising the Value from Corporate Image. Harvard Business School Press. Boston. MA.

Fombrun, C., Gardberg, N.A. \& Sever, J.M. (2000), "The reputation quotient: a multistakeholder measure of corporate reputation”. Journal of Brand Management, 7(4), 241-55.

Ganesan, S. (1994). Determinants of long-term orientation in buyer-seller relationships. Journal of Marketing, 58(April), 1-19.

Garbarino, E., \& Johnson, M.S. (1999). The Different Roles of Satisfaction, Trust, and Commitment in Customer Relationships. Journal of Marketing 63(April), 70-87.

Gotsi, M. \& Wilson, A.M. (2000). Corporate reputation: seeking a definition. Corporate Communications: An International Journal, 6(1), 24-30.

Gray, E.R., \& Balmer, J.M.T. (1998). Managing Corporate Image and Corporate Reputation. Long Range Planning, 31(5), 695-702.

Gremler, D.D. (1994). Word-of-mouth about service providers: an illustration of theory development in marketing. In AMA Winter Educators' Conference Proceedings: 
Marketing Theory and Applications (Ed.), In Park, C. W. and Smith D. (Eds.), (pp. 6270). Chicago, IL. American Marketing Association.

Guba, E.G., \& Lincoln, Y.S. (1994). Competing paradigms in qualitative research. In N. K. Denzin and Y. S. Lincoln (Eds.), Handbook of qualitative research (pp. 105-117). Thousand Oaks, CA: Sage.

Hansen, H., Samuelsen, B.M., \& Silseth, P.R. (2008). Customer perceived value in B-to-B service relationships: Investigating the importance of corporate reputation. Industrial Marketing Management, 37, 206-217.

Helm, S. (2006). Exploring the Impact of Corporate Reputation on Consumer Satisfaction and Loyalty. Journal of Customer Behaviour, 5(1), 59-80.

Helm, S. (2007). The Role of Corporate Reputation in Determining Investor Satisfaction and Loyalty. Corporate Reputation Review, 10(1) 22-37.

Hennig-Thurau, T., Gwinner, K.P., Walsh, G., \& Gremler, D.D. (2004). Electronic word-ofmouth via consumer-opinion platforms: what motivates consumers to articulate themselves on the Internet? Journal of Interactive Marketing, 18(1), 38-52.

Hoyer, W.D. \& MacInnis, D.J. (2001). Consumer Behaviour. Houghton-Mifflin. Boston. MA.

Jahdi, K., \& Acikdilli, G. (2009). Marketing Communications and Corporate Social Responsibility (CSR): Marriage of Convenience or Shotgun Wedding? Journal of Business Ethics, 88(1), 103-113.

Kirmani, A. \& Rao, A.R. (2000). No Pain, No Gain: A Critical Review of the Literature on Signaling Unobservable Product Quality. American Journal of Marketing, 64(2), 66-79.

Koronis, E., \& Ponis, S.T. (2012). Introducing Corporate Reputation Confnuity To Support Organizational Resilience Against Crises. Journal of Applied Business Research 28(2), 283-290.

Lindlof, T.R. (2010). Qualitative Communication Research Methods. Sage Thousand Oaks, CA.

Miles, M.B., \& Huberman, A.M. (1994). Qualitative Data Analysis: A Source Book of New Methods. Sage. Newbury Park.

Moffitt, M.A. (1994). A cultural studies perspective toward understanding corporate image: A case study of State Farm Insurance. Journal of Public Relations Research, 6, 41-66.

The Daily Telegraph (London). (2007). Doing a Ratner and other famous gaffes, 22 December.

Park, C., \& Lee, T.M. (2007). Information direction, website reputation and eWOM effect: A moderating role of product type. Journal of Business Research, 62 (2009) 61-67.

Peck, H.L., Payne, A., Christopher, M., \& Clark, M. (1999). Relationship Marketing, Strategy and Implementation. Butterworth-Heinemann. Oxford.

Perry, C., Reige, A., \& Brown, L. (1999). Realism's role among scientific paradigms in marketing research. Irish Marketing Review, 12(2), 16-23.

Richard, J.E., \& Zhang, A. (2012). Corporate image, loyalty, and commitment in the consumer travel industry. Journal of Marketing Management, 28(5/6), 568-593.

Roberts, C., \& Alpert, F. (2010). Total Customer Engagement: Designing and aligning strategic elements to achieve growth. Journal of Product \& Brand Management, 19(3), 199-209.

RepuTex Report (2003). See ABC lateline Broadcast: 13/10/2003 accessed 19/10/2012 http://www.abc.net.au/lateline/content/2003/s966137.htm

Reuber, A.R. \& Fischer, E. (2005). The company you keep: How young firms in different competitive contexts signal reputation through their customers. Entrepreneurship Theory and Practice, 29(1), 57-78.

Rogerson, W.P. (1983). Reputation and product quality. The Bell Journal of Economics, 14(2), 508-516. 
Rubin, M. D. (1995). Reinventing Customer Management: Lessons from the Best of the Best. Prism, Cambridge Massachusetts 4, 25-40.

Rubin, H. J. \& Rubin, I. (2005). Qualitative interviewing: the art of hearing data. $2^{\text {nd }}$ (ed), Sage. Thousand Oaks. CA.

Scapens, R.W. (1990). Researching management accounting practice: the role of case study methods. British Accounting Review 22, 259-281.

Selnes, F. (1993). An examination of the effect of product performance on brand reputation, satisfaction and loyalty. European Journal of Marketing, 27(9), 19-34.

Seppänen, R., Blomquvist, K., \& Sundqvist, S. (2007). Measuring inter-organizational trust-A critical review of the empirical research in 1990-2003, International Marketing Management, 36, 249-265.

Shenkar, O. \& Yuchtman-Yaar, E. (1997). Reputation, image, prestige and goodwill. An interdisciplinary approach to organizational standing. Human Relations, 50(11), 13611381.

Sichtmann, C. (2007). An analysis of antecedents and consequences of trust in a corporate brand. European Journal of Marketing, 41(9/10), 999-1015.

Söderlund, M. (1998). Customer satisfaction and its consequences on customer behaviour revisited: The impact of different levels of satisfaction on word-of-mouth, feedback to the supplier and loyalty. International Journal of Service Industry Management, 9(2), 169-188.

Stanaland, A., Lewin, M., \& Murphy, P. (2011). Consumer Perceptions of the Antecedents and Consequences of Corporate Social Responsibility. Journal of Business Ethics, 102(1), 47-55.

Sullivan, J., Peterson, R.B., Kameda, N., \& Shimada, J. (1981). The Relationship Between Conflict Resolution Approaches and Trust -A Cross Cultural Study. Academy of Management Journal, 24(4), 803-815.

Svensson, G. (2001). Extending trust and mutual trust in business relationships towards a synchronised trust chain in marketing channels. Management Decision, 39(6), 431-440.

Tsoukas, H. (1989). The validity of idiographic research explanations. Academy of Management Review, 24(4), 551-561.

United Breaks Guitars. (2012). http://www.sonsofmaxwell.com/ YouTube accessed 19/10/2012.

Walsh, G., Mitchell, V.-W., Jackson, P.R., \& Beatty, S.E. (2009). Examining the antecedents and consequences of corporate reputation: A customer perspective. British Journal of Management, 20(2), 187-203.

Weber Shandwick Report. (2011). The Company Behind the Brand: In Reputation We Trust.

Weigelt, K. \& Camerer, C. (1988). Reputation and corporate strategy: a review of recent theory and applications. Strategic Management Journal, 9, 443-54.

Weiss, A.M., Anderson, E. \& MacInnis, D.J. (1999). Reputation management as a motivation for sales structure decisions. Journal of Marketing, 63(4), 74.

Yin, R.K. (1994). Case Study Research: Design and Methods. (2nd edition). Sage, Thousand Oaks. CA.

Yin, R.K. (2003). Case Study Research: Design and Methods. ( ${ }^{\text {rd }}$ edition). Sage, Thousand Oaks. CA.

\footnotetext{
${ }^{1}$ View the clip: www.youtube.com/watch?v=5YGc4zOqozo
} 